\title{
Mammalian Cell
}

National Cancer Institute

\section{Source}

National Cancer Institute. Mammalian Cell. NCI Thesaurus. Code C12958.

A cell originating from or isolated from an animal of class Mammalia. 